\title{
Adherence to diabetes mellitus treatments in Family Health Strategy Units*
}

\author{
ADESÃO AO TRATAMENTO EM DIABETES MELLITUS EM UNIDADES DA ESTRATÉGIA \\ SAÚDE DA FAMÍLIA
}

\section{ADHERENCIA AL TRATAMIENTO DE LA DIABETES MELLITUS EN UNIDADES DE ESTRATEGIA DE LA SALUD DE LA FAMILIA}

\author{
Heloisa Turcatto Gimenes Faria ${ }^{1}$, Manoel Antônio dos Santos ${ }^{2}$, Clarissa Cordeiro Alves \\ Arrelias $^{3}$, Flávia Fernanda Luchetti Rodrigues ${ }^{4}$, Jefferson Thiago Gonela ${ }^{5}$, Carla Regina de \\ Souza Teixeira ${ }^{6}$, Maria Lúcia Zanetti ${ }^{7}$
}

\section{ABSTRACT}

This cross-sectional study aimed to analyze the adherence to drug and non-drug treatments in 17 Family Health Strategy units. A total of 423 patients with type 2 diabetes mellitus were selected through stratified random sampling in Family Health Strategy units of a city in the state of Minas Gerais, Brazil, in 2010. The results showed that the prevalence rate of adherence to drug therapy was higher than $60 \%$ in the 17 units investigated; in relation to physical activity, adherence was higher than $60 \%$ in $58.8 \%$ units; and for the diet plan, there was no adherence in $52.9 \%$ units. Therefore, we concluded that adherence to drug therapy in most units was high and the practice of physical activity was heterogeneous, and in relation to diet adherence, it was low in all units. We recommend strengthening of institutional guidelines and educational strategies, in line with SUS guidelines, so that, professionals may face the challenges imposed by the lack of adherence.

\section{DESCRIPTORS}

Diabetes mellitus

Medication adherence

Family health

Health evaluation

Primary Health Cared

\section{RESUMO}

Estudo transversal que teve como objetivo analisar a adesão ao tratamento medicamentoso e não medicamentoso em 17 unidades da Estratégia Saúde da Família (ESF). Participaram 423 pacientes com diabetes mellitus tipo 2 selecionados por meio de amostragem aleatória estratificada, nas unidades da ESF de um município do interior de Minas Gerais, em 2010. Os resultados mostraram que a adesão ao tratamento medicamentoso foi superior a $60 \%$ nas 17 unidades investigadas; em relação à atividade física foi superior a $60 \%$ em $58,8 \%$ das unidades; entretanto, para o plano alimentar, foi nula em $52,9 \%$ das unidades. Conclui-se que a adesão ao tratamento medicamentoso foi alta na maioria das unidades; a prática de atividade física foi heterogênea e, em relação ao plano alimentar foi baixa em todas as unidades. Recomenda-se o fortalecimento das diretrizes institucionais e estratégias educativas, em consonância com as diretrizes do SUS, para o enfrentamento dos desafios impostos pela falta de adesão.

\section{DESCRITORES \\ Diabetes mellitus \\ Adesão à medicação \\ Saúde da família \\ Avaliação em saúde \\ Atenção Primária à Saúde}

\begin{abstract}
RESUMEN
Estudio transversal, cuyo objetivo fue analizar la adherencia al tratamiento farmacológico y no farmacológico en 17 unidades de Estrategia Salud de la Familia (ESF). Participaron 423 pacientes con diabetes mellitus tipo 2 seleccionados mediante muestreo aleatorio estratificado en unidades de ESF de un municipio de Minas Gerais en el año 2010. Los resultados mostraron que la tasa de prevalencia de la adherencia al tratamiento farmacológico fue superior a $60 \%$ en las 17 unidades investigadas; en relación a la actividad física, ésta fue superior a $60 \%$ en el $58,8 \%$ de las unidades; y para el plan de alimentación, no tuvo efecto en 52,9\% de las unidades. Se concluye que: la adherencia al tratamiento farmacológico fue alta en la mayoría de las unidades, la práctica de actividad física fue heterogénea y la adherencia a la dieta fue baja en todas las unidades. Se recomienda el fortalecimiento de las normas institucionales y estrategias educativas en consonancia con las directrices del SUS para hacer frente a los desafíos impuestos por la falta de adherencia.
\end{abstract}

\author{
DESCRIPTORES \\ Diabetes mellitus \\ Complimiento de la medicación \\ Salud de la Familia \\ Evaluación en salud \\ Atención Primaria de Salud
}

\begin{abstract}
*Extracted from the thesis "Challenges to health care: treatment adherence and metabolic control in people with type 2 diabetes mellitus in Passos, MG", School of Nursing of Ribeirão Preto, University of São Paulo, 2011. ${ }^{1}$ Professor of Libertas - Integrated Colleges of São Sebastião do Paraíso, Minas Gerais, Brazil. helogimenes@hotmail.com ${ }^{2}$ Associate Professor III, Department of Psychology, Faculty of Philosophy, Sciences and Languages of Ribeirão Preto, University of São Paulo, Ribeirão Preto, SP, Brazil. masantos@ffclrp.usp.br ${ }^{3}$ Master's student from the Graduate Program in Fundamental Nursing, School of Nursing of Ribeirão Preto, University of São Paulo, Ribeirão Preto, SP, Brazil. claarrelias@usp.br ${ }^{4}$ PhD candidate from the Graduate Program in Fundamental Nursing, School of Nursing of Ribeirão Preto, University of São Paulo, Ribeirão Preto, SP, Brazil. flavialuchetti@gmail.com ${ }^{5}$ PhD candidate of the Graduate Program in Fundamental Nursing, School of Nursing of Ribeirão, University of São Paulo, Ribeirão Preto, SP, Brazil. jeffersoneduca@usp.br ${ }^{6}$ Associate Professor, Department of General and Specialized Nursing, School of Nursing of Ribeirão Preto, University of São Paulo, Ribeirão Preto, SP, Brazil. carlarst@eerp.usp. br ${ }^{7}$ Associate Professor III, Department of General and Specialized Nursing, Nursing School of Ribeirão Preto, University of São Paulo, Ribeirão Preto, SP, Brazil.zanetti@eerp.usp.br
\end{abstract}

$\begin{aligned} \text { Rev Esc Enferm USP } & \text { Received: } 12 / 09 / 2013 \\ 2014 ; \text { 48(2):254-60 } & \text { Approved: 01/29/2014 }\end{aligned}$




\section{INTRODUCTION}

Adherence is defined as the measure to which a person's behavior - taking medication, following a diet plan or adopting changes in lifestyle, meets the recommendations suggested by a health professional ${ }^{(1)}$.

In the control of diabetes mellitus (DM), the lack of adherence to treatment is a challenge often faced by the professionals of health institutions in clinical practice ${ }^{(2-3)}$. Thus, intervention strategies aimed at minimizing this situation in diabetes care must be sought.

Factors involved in adherence include: accessibility and availability of drugs in health services, demographic data from users, acceptability of the medication, loss of sense of control over one's body, friends and family attitudes, social isolation, relationship between user and health professional, therapeutic regimen, chronicity, absence of symptoms, time to diagnosis, knowledge and understanding of the disease and treatment ${ }^{(4-10)}$.

When considering the current policy of the Brazil's Ministry of Health, from the Family Health Strategy (FHS), the conditions for the reorientation of health care model, replacing the traditional model of care were created.

Health actions implemented by Family Health teams have allowed increasing new relationships between health professionals, families and communities, guided by the establishment of connection and creating bonds of commitment and responsibility among health professionals and the public, which facilitates the identification and care of community health problems, such as lack of adherence to treatment in $\mathrm{DM}^{(11)}$. However, there is still lack of evaluation studies that allow us to know the outcomes self-related by the health care model in relation to the percentages of adherence to drug and non-drug treatments in the Family Health Units (FHS) ${ }^{(12)}$.

Given these challenges, we ask: what is the adherence to drug and non-drug treatments to control diabetes in FHS units in a city in the state of Minas Gerais, Brazil?

Based on this, the present study aimed to identify adherence to drug and non-drug treatments in 17 FHS units from a city in Minas Gerais, Brazil. It is expected to contribute to the redirection of the actions implemented in diabetes care in the primary care network services.

\section{METHOD}

This is a quantitative, cross-sectional, descriptive, observational study conducted from February to December of 2010 in the city of Passos, Minas Gerais, Brazil. The study population consisted of 1,406 individuals with type $2 \mathrm{DM}$ (T2DM) registered in $17 \mathrm{FHS}$ units that corresponds to SUS (Unified Health System) network for Primary Care service in the referred city. It is worth noting that the FHS program coverage in the city is more than $70 \%$ of the total population, which justifies the choice of this population.

The study included patients aged over 18 years old, diagnosed with T2DM, with a drug therapy prescription to control the disease, cognitive and hearing abilities preserved, monitored to referred FHS. Women with gestational diabetes and patients who used insulin were excluded.

The sample was calculated using the formula for crosssectional studies of infinite population, based on a conservative adherence prevalence of $50 \%$, which allowed the best possible quantitative number of participants. The calculation of sample size resulted in 421 people with T2DM. When considering a possible loss of sample due to denials, hospitalizations, dropouts, misinformation and/or not availability, a 20\% increase was made, totaling 505 individuals.

The sample was probabilistic, type random stratified, based on the percentage of people with T2DM who were registered in each of the 17 FHS. A total of 505 patients were selected, of whom 14 were not found at home, 12 refused to participate in the study, six have denied the diagnosis of T2DM, 25 were excluded because they used insulin, 11 have moved from their address, five did not use pharmacological therapy for T2DM, three had visual and hearing impairment and five died, totaling 82 (16.2\%) sample loss. Thus, the sample consisted of 423 patients with T2DM, who met the inclusion criteria.

To collect data for the study, four instruments were used: 1) a questionnaire containing sociodemographic variables (gender, age, education and household income), clinical (time of diagnosis, comorbidities, chronic complications), metabolic control (Body Mass Index - BMI, waist circumference WC, blood pressure - BP and laboratory tests); 2) Measure Treatment Adherence - MTA: instrument used to assess the patient's behavior in relation to everyday use of prescription drugs, which consists of seven items on a Likert six-point scale from 1 (always) to 6 (never) ${ }^{(13)}$; 3) Self-administered foodfrequency questionnaire (FFQ) assesses consumption of ten food groups according to the number of times, and unit size consumed portions ${ }^{(14)}$; and 4) International Physical Activity Questionnaire (IPAQ), short version: consisting of eight questions that assess the level of habitual physical activity, from information about the frequency and duration of physical activity, as well as the time spent in the sitting position ${ }^{(15)}$.

Data collection was conducted by field researchers, previously selected and trained. Sociodemographic, clinical, MTA, FFQ and IPAQ were obtained through structured interviews conducted in patients' homes. The average duration of each interview was 40 minutes. Data from $B P$, weight, height, WC and laboratory tests were collected in the 17 FHS units, after prior notice and guidance on fasting. To obtain the values of BP, weight, height and WC, the standard procedures in the literature were used ${ }^{(16-17)}$. Patients on medication to control blood pressure and diabetes, received special recommendations. The study was conducted from February to December 2010. 
For data analysis, we followed the criteria proposed by SBD (2011) for BP, weight, height, WC and laboratory tests. BP $>130 / 85 \mathrm{mmHg}$ was considered high. In relation to body weight, we considered $\mathrm{BMI} \geq 30$ an indicator of obesity. For the WC, we considered values $>102 \mathrm{~cm}$ for men and $88 \mathrm{~cm}$ for women. Altered values of total cholesterol $>200 \mathrm{mg} / \mathrm{dl}$, glycated hemoglobin A1c (HbA1c) >7, triglycerides $>150 \mathrm{mg} / \mathrm{dl}$, lipoprotein cholesterol of high density (HDL-C) $>100 \mathrm{mg} / \mathrm{dl}$ and lipoprotein cholesterol of low density (LDL-C) $<45 \mathrm{mg} / \mathrm{dl}$ were considered.

In the questionnaire MTA, patients were considered adherent and non-adherent who obtained values $\geq 5$ points and $<5$, respectively. Patients were considered as treatment non-adherence values obtained 1 to 4 , relating the answers always, very often, often and sometimes. To characterize treatment adherence, we considered the values 5 and 6 , corresponding to the responses rarely and never ${ }^{(18)}$.

Data obtained through the FFQ were entered into the Dietsys software version $4.0^{(19)}$ and, through this software, we obtained the average of the total caloric value (TCV) consumed by each individual, amount of fiber and cholesterol in $\mathrm{mg}$, along with the percentage of carbohydrates, protein, total and saturated fat compared to TCV. The calculation of TCV and macronutrients was carried from the coding responses on the frequency of consumption of each food in the FFQ.

For the FFQ, we considered adherent patients who attended at least three of the six nutritional recommendations established by the Brazilian Diabetes Society $(\mathrm{SBD})^{(20)}$, ie, consumption of total carbohydrates, dietary fiber and fractioning of meals. We chose these three recommendations because of the direct relationship to glycemic control of patients with DM.

For the analysis of IPAQ, first, patients were classified into four categories: sedentary, insufficiently active, moderately active and very active. Physical activity was described in: type of activity according to IPAQ - walking, moderate activity and vigorous activity, and total physical activity in MET. Physical inactivity was assessed by the daily and weekly sitting time, measured in minutes/day and minutes/ week, classified into quartiles. To define the level of physical activity, the metabolic equivalent (MET) derivative time in minutes/week in specific activities was considered, which was estimated from the compendium of Ainsworth ${ }^{(21)}$ and combined the frequency with which the activities were performed. In this study were considered adherent patients who were classified in moderately active and very active categories and non-adherent those included in the inactive and insufficiently active categories.

For data analysis of body mass index (BMI) and waist circumference, laboratory tests and blood pressure, we followed the recommendations of the World Health Organization $(\mathrm{WHO})^{(22)}$ and $\mathrm{SBD}^{(20)}$, respectively. To organize the data, a database was created in $\mathrm{SAS}^{\circledR} 9.0$ statistical software, performing double entry. For each FHS unit a number was assigned (FHS 1, FHS 2... FHS 17). Data were analyzed using descriptive statistics. For data presentation the absolute and percentages values were used. The project was approved by the Ethics Committee on Human Research of the School of Nursing of Ribeirão Preto, University of São Paulo (protocol no. 0990/2009).

\section{RESULTS}

From the 423 (100\%) patients, the mean age was 62.4 $(S D=11.8)$ years with a predominance of females $(66.7 \%)$; in relation to education, the mean in number of years of study was $4.3(S D=3.6)$, the average family income was U\$ 886.95 (SD=2744.4) dollars. Most patients (58.4\%) had less than ten years of diagnosis time, with an average of 9 years $(S D=6.6)$. The main comorbidities related to $\mathrm{DM} 2$ were: hypertension (81.3\%) and dyslipidemia (32.4\%). Regarding chronic complications, the highlights were: retinopathy $(37.8 \%)$ and heart disease $(20.3 \%)$. Patients obese were $18.9 \%, 76.1 \%$ and $73.7 \%$ had elevated waist circumference number and blood pressure, respectively. With the exception of total cholesterol (48.9\%), all other laboratory parameters were altered in the majority of the sample: HbA1c (75.2\%), triglycerides (60.3\%), HDL-C (65.6\%) and LDL-C (68.7\%).

Table 1 shows the numbers of patients examined in each FHS unit. It is noteworthy that, from the sample, the majority of patients were registered in the FHS 2 (8.0\%), followed by FHS 5 (7.8\%) and FHS 9 (7.8\%). The lowest sample $(2.8 \%)$ was from the FHS 1.

Table 1 - Number and percentage of patients with DM2, registered at the FHS, according to the FHS they belong to - Passos, MG, Brazil 2010

\begin{tabular}{rrr}
\hline FHS & N & \% \\
\hline 1 & 12 & 2.8 \\
3 & 34 & 8.0 \\
4 & 25 & 5.9 \\
5 & 32 & 7.6 \\
6 & 33 & 7.8 \\
7 & 24 & 5.7 \\
8 & 15 & 3.5 \\
9 & 25 & 5.9 \\
10 & 33 & 7.8 \\
11 & 20 & 4.7 \\
12 & 19 & 4.5 \\
13 & 22 & 5.2 \\
14 & 23 & 5.4 \\
15 & 24 & 5.7 \\
16 & 30 & 7.1 \\
17 & 27 & 6.4 \\
\hline Total & 25 & 5.9 \\
\hline Note: (N $=423)$. & $\mathbf{4 2 3}$ & $\mathbf{1 0 0 . 0}$ \\
\hline & &
\end{tabular}

Adherence to diabetes mellitus treatments in Family Health Strategy Units 
The results showed that $84.4 \%$ of patients had adherence to drug therapy, $58.6 \%$ for physical activity and only $3.1 \%$ to the diet plan. Analysing simultaneously the three elements investigated, we note that only six (1.4\%) patients had total adherence to the treatments for T2DM, $49.4 \%$ had adherence to two treatment plans, so $47.7 \%$ combined drug therapy and physical activity and 43 (6.2 $\%)$ had adherence to one or none of the treatments for DM2, respectively.

Table 2 shows the number and percentage distribution of patients in each FHS adhering to drug therapy, diet plan and physical activity in relation to the total number of patients investigated in each unit. It is observed that adherence to medication was greater than $60 \%$ in all units investigated, highlighting the FHS 5, which had the highest percentage (93.9\%).

Table 2 - Numerical and percentage distribution of patients in each FHS adhering to drug treatment, Diet plan and physical activity in relation to the total number of patients investigated in each FHS - Passos, MG, Brazil 2010

\begin{tabular}{cccc}
\hline & \multicolumn{3}{c}{ Adherence to treatment } \\
\cline { 2 - 4 } FHS & $\begin{array}{c}\text { Drug therapy } \\
\text { (MTA) }\end{array}$ & Diet plan (FFQ) & $\begin{array}{c}\text { Physical activity } \\
\text { (IPAQ) }\end{array}$ \\
\cline { 2 - 4 } & $\mathbf{n ~ ( \% )}$ & $\mathbf{n ~ ( \% )}$ & $\mathbf{n}(\%)$ \\
\hline 1 & $8(66.7)$ & - & $12(100.0)$ \\
2 & $27(79.4)$ & $1(2.9)$ & $16(47.1)$ \\
3 & $23(92.0)$ & - & $7(28.0)$ \\
4 & $23(71.9)$ & $1(3.1)$ & $20(62.5)$ \\
5 & $31(93.9)$ & - & $15(45.4)$ \\
6 & $21(87.5)$ & - & $11(45.8)$ \\
7 & $14(93.3)$ & - & $5(33.3)$ \\
8 & $20(80.0)$ & $2(8.0)$ & $6(24.0)$ \\
9 & $28(84.8)$ & $2(6.1)$ & $26(78.8)$ \\
10 & $16(80.0)$ & $1(5.0)$ & $15(75.0)$ \\
11 & $16(84.2)$ & $1(5.3)$ & $15(78.9)$ \\
12 & $18(81.8)$ & $2(9.1)$ & $11(50.0)$ \\
13 & $18(78.3)$ & - & $14(60.9)$ \\
14 & $22(91.7)$ & - & $15(62.5)$ \\
15 & $26(86.7)$ & - & $25(83.3)$ \\
16 & $24(88.9)$ & - & $19(70.4)$ \\
17 & $22(88.0)$ & $3(12.0)$ & $16(64.0)$ \\
\hline
\end{tabular}

Note: $(\mathrm{N}=423)$.

In relation to their diet plan, more than half, or $52.9 \%$ of FHS patients were non-adherent to treatment. In the FHS where there was adherecence, the highest percentage was $12 \%$, observed in the FHS 17.

In this variable, we also observed variability in the results depending on the unit, but with smaller amplitude of variation of adherence: $2.9 \%$ to $12 \%$. Regarding physical activity, adherence ranged from 24 to $100 \%$, having highlighted the FHS 1 . This was the largest variability observed between FHS units. It is noteworthy that $58.8 \%$ of the units showed adherence to physical activity greater than $60 \%$.

Table 3 shows the numerical and percentage distribution of total patients registered in the FHS that adhered to drug therapy, the diet plan and physical activity. It is observed that, from the 423 patients studied, 357 showed adherence to drug therapy, 13 to diet plan and 248 to physical activity. Of those with adherence to drug therapy for the control of diabetes, $8.7 \%$ were from FHS 5. As to diet, the majority (23.0\%) was registered in the FHS 17. Regarding physical activity, 10.5 and 10.1\% came from FHS 9 and 15, respectively.

Table 3 - Numerical and percentage distribution of total patients registered in the FHS that adhered to drug therapy, diet plan and physical activity. Passos, MG, Brazil 2010

\begin{tabular}{|c|c|c|c|}
\hline \multirow{3}{*}{ FHS } & \multicolumn{3}{|c|}{ Adherence to treatment } \\
\hline & $\begin{array}{l}\text { Drug therapy } \\
\text { (MTA) }\end{array}$ & Diet plan (FFQ) & $\begin{array}{l}\text { Physical activity } \\
\text { (IPAQ) }\end{array}$ \\
\hline & n (\%) & n (\%) & n (\%) \\
\hline 1 & $8(2.2)$ & - & $12(4.9)$ \\
\hline 2 & $27(7.6)$ & $1(7.7)$ & $16(6.5)$ \\
\hline 3 & $23(6.4)$ & _ & $7(2.8)$ \\
\hline 4 & $23(6.4)$ & $1(7.7)$ & $20(8.1)$ \\
\hline 5 & $31(8.7)$ & - & $15(6.0)$ \\
\hline 6 & $21(5.9)$ & _ & $11(4.4)$ \\
\hline 7 & $14(4.0)$ & _ & $5(2.0)$ \\
\hline 8 & $20(5.6)$ & $2(15.4)$ & $6(2.4)$ \\
\hline 9 & $28(7.8)$ & $2(15.4)$ & $26(10.5)$ \\
\hline 10 & $16(4.5)$ & $1(7.7)$ & $15(6.0)$ \\
\hline 11 & $16(4.5)$ & $1(7.7)$ & $15(6.0)$ \\
\hline 12 & $18(5.0)$ & $2(15.4)$ & $11(4.4)$ \\
\hline 13 & $18(5.0)$ & - & $14(5.7)$ \\
\hline 14 & $22(6.2)$ & - & $15(6.0)$ \\
\hline 15 & $26(7.3)$ & _ & $25(10.1)$ \\
\hline 16 & $24(6.7)$ & - & $19(7.7)$ \\
\hline 17 & $22(6.2)$ & $3(23.0)$ & $16(6.5)$ \\
\hline Total & $357(100)$ & $13(100)$ & $248(100)$ \\
\hline
\end{tabular}

With regard to DM treatment adherence, from the 17 FHS investigated, one stood out as the adherence of the users of the health service in relation to drug therapy, another in the diet plan and in another one physical activity practice. Two units showed good results for the three elements that comprise the therapeutic strategy for DM control: drug therapy, diet plan and physical activity.

The adhesion measurements found in these units may reflect the policy of diabetes care adopted by the State Department of Health, which recommends continuous monitoring of patients with DM by FHS teams, in order to 
promote the control of the disease, prevent complications, reduce costs and encourage adherence to treatment ${ }^{(23)}$.

Adherence to diet plan was low in all the evaluated units. It is recognized that the adherence of user to the diet plan is one of the biggest challenges of the FHS teams, due to the complexity involved in feeding behavior. These results may reflect the importance of supporting the promotion and development of actions to strengthen internal resources for user to adapt the recommended diet plan, as well as the necessary social support for adherence to treatments without drugs ${ }^{(24-26)}$.

On the other hand, adherence to physical activity was high in all units. One can attribute this result to the contemporary culture of care for the body and search for wellbeing, or the incorporation of self-care behavior, programmatically encouraged by the actions of the FHS. Investments in outdoor gyms, bike paths, parks, among others, as a public health policy, it can contribute to the adherence of physical activity in the general population, including people with $\mathrm{DM}^{(27)}$.

In relation to drug therapy, it was found that adherence was greater than $60 \%$ in all FHS units investigated. This data can be conditioned to various factors such as the policy of free distribution of drugs by SUS health network, ensuring accessibility to these medicines, as well as the ease of taking the medication. These data corroborate other studies that show adherence to drug therapy is high ${ }^{(28-29)}$. The high percentages are related to the acceptability of drug therapy and the belief in the efficacy for disease control. Moreover, adherence to regular physical activity and eating plan depends on complex factors such as socio-cultural values, motivation for change in attitude, knowledge about the disease, access to suitable location for practicing physical activity, ergometric tests for statement of appropriate physical activity and monitoring of patients by a physical educator and nutritionist at public health unit ${ }^{(25,29-30)}$.

By comparing the rates of adherence to treatment for DM in different FHS, there was great variability in the measurements for drug therapy and physical activity. These results suggest that the distribution policy related to medicines and the support for the development of physical activity, may show variability in the benefits achieved and other variables, which were not subject of this study, but could explain the heterogeneity found in the units investigated.

On the other hand, the indicators, such as BP, WC, lipid profile and $\mathrm{Hb} 1 \mathrm{c}$ show that the control of the disease was altered. It is recognized that patients may be already benefiting from public policies implemented for the control of chronic diseases such as DM, however, it is possible to postulate that any benefits have not resulted in improved metabolic control indicators. Thus, the FHS, as advocated for attention to the reorganization of the health system in Brazil from the Primary Health Care model, should make efforts to better understand the complexity of adherence to drug and non-drug therapy for diabetes.
Understanding the barriers involved in low adherence to the pillars of the DM treatment in public units enables the reorientation of health actions, with local resources for overcoming obstacles to the effectiveness of the goals advocated by the FHS ${ }^{(12)}$. Thus, it will be possible to implement strategies to improve the health of the community.

Adherence to treatment can also be a useful indicator for assessing the effectiveness of care in diabetes, together with other factors related to the evaluation of services and programs such as: evaluation of coverage, accessibility and equity; efficacy, effectiveness and impact of health measures practices; efficiency in actions, quality and appropriateness of actions to technical-scientific knowledge of professionals; and patient satisfaction in relation to health practices offered ${ }^{(28)}$.

\section{CONCLUSION}

Adherence to drug therapy was positive in all FHS, showing that the public policy of free distribution of medicines by health care network and the primary care model adopted by the FHS may favor the percentages of adherence to drug therapy. Adherence to physical activity was also positive. This finding is promising because it reveals that this aspect of self-care is being incorporated into the treatment of diabetes. On the other hand, adherence to diet was worrying, which highlights the complexity of adopting new eating habits into adulthood. This factor is a key obstacle to changing habits of life, which was evident in all FHS investigated.

Given the findings in this study, the strengthening of institutional guidelines and educational strategies in line with the guidelines of SUS is recommended, so that adherence to diet, physical activity and drugs for the treatment of diabetes are considered effective indicators of the implementation of the principles of comprehensiveness in longitudinality and integrality in attention to diabetes in the city of this research. Furthermore, it is recommended that future studies, related to strategies aimed at identifying the individual risk for non-adherence, are carried out in order to know their predictor variables.

As limitation of the study, we highlight the need to explore why adherence is higher in some units than in others. Identifying contextual variables involved in this matter could contribute to the qualification of health professionals in the planning of interventions in diabetes. In this direction, we suggest studies to assess the capacity and configuration of the FHS units' staff in diabetes care, chronic disease complications, sociodemographic characteristics of users of health services, among other variables to better understand the phenomenon investigated.

Knowing adherence to drug and non-drug therapy has clinical relevance for Nursing, since it allows direct clinical decisions regarding the treatment of diabetes in FHS team.
Adherence to diabetes mellitus treatments in Family Health Strategy Units 


\section{REFERENCES}

1. World Health Organization(WHO). Adherence to long-term therapies: evidence for action. Geneva: WHO; 2003.

2. Araújo MFM, Freitas RWJF, Fragoso LVC, Araújo TM, Damasceno MMC, Zanetti ML. Cumprimento da terapia com antidiabéticos orais em usuários da atenção primária. Texto Contexto Enferm. 2011;20(1):135-43.

3. Sarti TD, Campos CEA, Zandonado E, Ruschi GEC, Maciel ELN. Avaliação das ações de planejamento em saúde empreendidas por equipes de saúde da família. Cad Saúde Pública. 2012;28(3):537-48.

4. Valle EA, Viegas EC, Castro CAC, Toledo Junior AC. A adesão ao tratamento. Rev Bras Clín Ter. 2000;26(3):83-6.

5. Leite SN, Vasconcelos MPC. Adesão à terapêutica medicamentosa: elementos para a discussão de conceitos e pressupostos adotados na literatura. Ciênc Saúde Coletiva. 2003;8(3):775-82.

6. Mann DM, Ponieman D, Leventhal H, Halm EA. Predictors of adherence to diabetes medications: the role of disease and medication beliefs. J Behav Med. 2009;32(3):278-84.

7. Broadbent E, Donkin L, Stroh JC. Illness and treatment perceptions are associated with adherence to medications, diet, and exercise in diabetic patients. Diabetes Care. 2011; 34(2):338-40.

8. Costa JA, Balga RSM, Alfenas RCG, Cotta RMM. Promoção da saúde e diabetes: discutindo a adesão e a motivação de indivíduos diabéticos participantes de programas de saúde. Ciênc Saúde Coletiva. 2011;16(3):2001-9.

9. Gherman A, Schnur J, Montgomery G, Sassu R, Veresiu I, David $D$. How are adherent people more likely to think? A meta-analysis of health Beliefs and diabetes self-care. Diabetes Educ. 2011;37(3):392-408.

10. Santos MA, Alves RCP, Oliveira VA, Ribas CR, Teixeira CR, Zanetti ML. Social representations of people with diabetes regarding their perception of family support for the treatment. Rev Esc Enferm USP [Internet]. 2011 [cited 2013 Sept 17];45(3):651-8. Available from: http://www.scielo.br/pdf/ reeusp/v45n3/en_v45n3a15.pdf

11. Brasil. Ministério da Saúde; Secretaria de Vigilância em Saúde, Departamento de Análise de Situação de Saúde. Plano de Ações Estratégicas para o Enfrentamento das Doenças Crônicas não Transmissíveis (DCNT) no Brasil 2011-2022. Brasília; 2011.

12. Silva ASB, Santos MA, Teixeira CRS, Damasceno MMC, Camilo J, Zanetti ML. Avaliação da atenção em diabetes mellitus em uma unidade básica distrital de saúde. Texto Contexto Enferm. 2011;20(3):512-8.
13. Delgado $A B$, Lima ML. Contributo para validação concorrente de uma medida de adesão aos tratamentos. Psicol Saúde Doenças. 2001;2(2):81-100.

14. Ribeiro $A B$, Cardoso $M A$. Construção de um questionário de frequência alimentar como subsídio para programas de prevenção de doenças crônicas não transmissíveis. Rev Nutr. 2002;15(2):239-45.

15. Matsudo SM, Araújo T, Matsudo V, Douglas A, Andrade E, Oliveira LC, et al. Questionário Internacional de Atividade Física (IPAQ): estudo de validade e reprodutibilidade no Brasil. Rev Bras Ativ Fís Saúde. 2001;6(2):5-18.

16. Sociedade Brasileira de Cardiologia, Departamento de Hipertensão Arterial. VI Diretrizes Brasileiras de Hipertensão Arterial. Rev Bras Hipertens. 2010;17(1):1-66.

17. Brasil. Ministério da Saúde; Secretaria de Atenção à Saúde, Departamento de Atenção Básica. Orientações para a coleta e análise de dados antropométricos em serviços de saúde: norma técnica do Sistema de Vigilância Alimentar e Nutricional - SISVAN. Brasília; 2011.

18. Faria HTG. Desafios para a atenção em saúde: adesão ao tratamento e controle metabólico em pessoas com diabetes mellitus tipo 2, no município de Passos, MG [tese doutorado]. Ribeirão Preto: Escola de Enfermagem de Ribeirão Preto, Universidade de São Paulo, 2011.

19. Block G, Coyle LM, Hartman AM, Scoppa SM. Revision of dietary analysis software for the Health Habits and History Questionnaire. Am J Epidemiol. 1994;139(12):1190-6.

20. Sociedade Brasileira de Diabetes (SBD). Diretrizes. Rio de Janeiro: SBD; 2011.

21. Ainsworth BE, Haskell WL, Whitt MC, Irwin ML, Swartz AM, Sjtrath SJ, et al. Compendium of physical activities: an update of activity codes and MET intensities. Med Sci Sports Exerc. 2000;32(9 Suppl):S498-516.

22. World Health Organization (WHO). Physical status: the use and interpretation of anthropometry. Geneva: WHO; 1995.

23. Minas Gerais. Secretaria de Estado de Saúde. Atenção à Saúde do Adulto: hipertensão e diabetes. 2a ed. Belo Horizonte: SAS/MG; 2007.

24. Ribas CRP, Santos MA, Zanetti ML. Representações sociais dos alimentos sob a ótica de pessoas com diabetes mellitus. Interam J Psychol. 2011;45(2):255-62.

25. Pontieri FM, Bachion MM. Crenças de pacientes diabéticos acerca da terapia nutricional e sua influência na adesão ao tratamento. Ciênc Saúde Coletiva. 2010;15(1):151-60. 
26. Gomes-Villas Boas LC, Foss MC, Foss-Freitas MC, Monteiro LC, Pace AM. Adesão à dieta e ao exercício físico das pessoas com diabetes mellitus. Texto Contexto Enferm. 2011;20(2):272-9.

27. Mendes EV. As Redes de Atenção à Saúde. Brasília: OPAS/ CONASS; 2011.

28. Hankó B, Kázmér M, Kumli P, Hrágyel Z, Samu A, Vincze Z, et al. Self-reported medication and lifestyle adherence in Hungarian patients with type 2 diabetes. Pharmm World Sci. 2007;29(2):58-66.
29. Gimenes HT, Zanetti ML, Haas VJ. Fatores relacionados à adesão do paciente diabético à terapêutica medicamentosa. Rev Latino Am Enferm. 2009;17(1):46-51.

30. Rodrigues FFL, Zanetti ML, Santos MA, Martins TA, Sousa VD, Teixeira CRS. Knowledge and attitude: important components in diabetes education. Rev Latino Am Enferm. 2009;17(4):468-73. 